\title{
Ecological Implications of Organic Mulches in Arboriculture: A Mechanistic Pathway Connecting the Use of Organic Mulches with Tree Chemical Defenses
}

\author{
Javier Lugo-Perez and John E. Lloyd
}

\begin{abstract}
In addition to the aesthetic and practical benefits of mulching, studies have shown indirect benefits of organic mulches to tree establishment and growth. These indirect benefits are associated with direct improvements on soil water and nutrient availability by mulches. The generalization of the organic mulches benefit to soil and trees has been questioned by several studies showing contradictory results under different experimental conditions and mulching materials. In addition, overall benefits for trees may be overlooked by focusing studies on some aspects of plant performance (e.g., plant growing rate) while ignoring others (e.g., plant chemical defense). This paper reviews studies showing how organic mulches can directly affect plant resource availability in the soil, presenting evidence from the literature that illustrates the influence of organic mulches on plant resource availability can also affect tree photosynthate allocation dynamics with direct consequences on plant chemical defenses. Based on the reviewed literature, presented here is a mechanistic pathway to illustrate how organic mulches can influence plant resources in the soil, and in turn how that can affect tree physiology and tree-insect interactions in urban areas.

Key Words. Growth-Differentiation Balance; Nitrogen Availability; Photosynthate Allocation; Water Availability.
\end{abstract}

Organic mulches are extensively used in urban systems to improve plant establishment and development (Acquaah 2004). Mulch is defined as "any material such as straw, sawdust, leaves, plastic film, and loose soil that is spread on the surface of the soil to protect the soil and plant roots from the effects of raindrops, soil crusting, freezing, and evaporation" (Brady and Weil 1999). This definition is based on mulch-substrate physical properties that benefit mostly soil structure and water content. Beside the physical benefits of mulching, this practice can increase or decrease the amount of inorganic $\mathrm{N}$ in the soil depending on the carbon $(\mathrm{C})$ to nitrogen (N) ratio (Melillo et al. 1982; Herms et al. 2001; Lloyd et al. 2002; Erhart and Hartl 2003). These alterations to the soil, that directly affect tree growth, can also affect the synthesis of chemical defenses and as consequence plant-herbivore interactions.

This paper proposes a mechanistic pathway to explain how the impact of organic mulches applied to the soil surface can influence patterns of tree resource uptake, $\mathrm{C}$ assimilation and $\mathrm{C}$ allocation between growth and chemical defenses. Present here is a model that illustrates pathway connections and identifies the three most likely affected processes: (i) soil resource availability (water and $\mathrm{N}$ ), (ii) plant $\mathrm{C}$ and $\mathrm{N}$ uptake, and (iii) plant $\mathrm{C}$ allocation between growth and the production of secondary compounds (Figure 1). The objective of this paper is to compile scientific evidence, pertinent for arboriculture, showing direct and indirect relationships among mulch application, soil resource availability and plant physiological responses. This review should increase awareness among arborists and scientists in the tree care industry to improve the utilization of organic mulches and promote further experimental studies in urban landscape scenarios.

\section{CONCEPTUAL FRAMEWORK}

\section{Effect of Organic Mulches on Resource Availability}

Organic mulches can affect the soil availability of two important resources for plants: water and N. Benefits of mulches to soil water content have been associated with the physical properties of mulches to buffer soil temperature (Mbagwu 1991; Bussiere and Cellier 1994). During days with high temperatures, a mulch layer protects soil surface from direct solar radiation. As a consequence, soil temperature remains cooler than air temperature and less water evaporates from the soil. Iles and Dosmann (1999) reported that 2-10 cm (0.79-4 in) of organic mulches (pine bark, pine wood, and hard wood chips) were more effective in reducing soil surface temperature [by $\left.\sim 2^{\circ} \mathrm{C}\left(3.6^{\circ} \mathrm{F}\right)\right]$ and increasing soil gravimetric water content [by $\sim 0.2 \mathrm{~g} \mathrm{~kg}^{-1}\left(3.2 \times 10^{-3} \mathrm{oz} \mathrm{lb}^{-1}\right)$ ] compared to inorganic mulches (pea gravel, lava rock, river rock and crushed red bricks) or bare soil. Furthermore, Appleton et al. (1990) found that, during summer days, when soil covered with fabric or plastic film to protect them from weed establishment were also mulched, soil temperature was lower and water content was higher than nonmulched soils independently of the weed control treatment. Although the influence of mulching on soil water content is frequently associated with reduction in soil temperature, De Vleeschauwer et al. (1980) showed that mulching can also improve water content by enhancing biological activity of soil macrofauna (e.g., earthworms) that increases soil porosity.

Despite the numerous studies reporting positive benefits of organic mulches on soil water content, other studies have also 
reported negative or no effect of mulching on plant water availability (Watson and Kupkowski 1991; Erhart and Hartl 2003, Gilman and Grabosky 2004, Cook et al. 2006). These contradictory results reflect the variability in application methods and mulch material. For example, Gilman and Grabosky (2004) reported that hydric stress on balled-and-burlapped oak trees increased proportionally to mulch depth, after two weeks of planting. This study shows that under conditions of low precipitation and/or low irrigation rate, mulch can intercept significant amounts of water, reducing soil water-recharging rates (Gilman and Grabosky 2004). Depending on the environmental conditions, this negative effect of mulch on soil water content could be aggravated by applying mulch layer thicker than recommended by the International Society of Arboriculture [5-10 cm (2-4 in)] (ISA 2004) and by using mulching substrates with high water holding capacity, such as farmyard manure compost (Cook et al. 2006).

Organic mulches also influence the availability of $\mathrm{N}$ in the soil. In general, organic matter increases soil labile $\mathrm{N}$ through leaching and decomposition (Lambers et al. 1998; Aerts and Chapin 2000). During decomposition, decaying plant material is broken down and incorporated in the soil as particulate organic matter (POM). Nitrogen is released from POM as soluble organic $\mathrm{N}$. Then, soil microorganisms may mineralize the dissolved organic $\mathrm{N}$ to ammonia $\left(\mathrm{NH}_{4}^{+}\right)$, which may be further oxidized to nitrate $\left(\mathrm{NO}_{3}^{-}\right)$. Ammonia and nitrate are considered the main sources of $\mathrm{N}$ used by plants in most ecosystems (Chapin 1995; Aerts and Chapin 2000). In non- or infrequently-fertilized systems, decomposition of plant material provides more than $90 \%$ of $\mathrm{N}$ supplied to plants (Lambers et al. 1998). For example, in Sitka spruce (Picea sitchensis) stands, system productivity of second rotation increased when branches and leaves from previous harvest episodes were left on site (Proe et al. 1996). The improvement in tree growth was attributed to the contribution of decomposing tree residues to the soil nutrient pool. The contribution was estimated to meet uptake requirements of second rotations for up to nine years (Proe et al. 1996).

Decomposition rate of decaying organic matter is highly controlled by environmental conditions, soil microbial activity and the organic matter chemical composition (Vitousek et al. 1994). Regarding organic matter chemical composition, studies have shown negative relationships between decomposition rates and the proportions of lignin: $\mathrm{N}$ and phenols: $\mathrm{N}$ ratios in decaying organic matter (Melillo et al. 1982; Vitousek et al. 1982; Northup et al. 1995; Aerts and De Caluwe 1997). Furthermore, the proportion of $\mathrm{C}: \mathrm{N}$ in the organic matter has been found to be the most consistent predictor of organic matter decomposition rate (Seneviratne 2000). Specifically, plant residues with high percentages of N (> $2 \%$ ), such as composted organic materials, show linear relationships with the amount of $\mathrm{N}$ released to the soil during decomposition (Seneviratne 2000). This pattern though, was better explained by the C:N proportion in the organic matter, rather than total $\mathrm{N}$.

As in decaying organic matter, decomposition rate of organic mulches is also influenced by the substrate $\mathrm{C}: \mathrm{N}$ ratio. Lloyd et al. (2002) compared the effect of two mulches made out of shredded wood pallets (C:N > 100:1) and composted yard-waste $(\mathrm{C}: \mathrm{N}<20: 1)$ on soil $\mathrm{N}$ dynamics. They found that mulched soils with yard-waste compost had higher levels of total $\mathrm{N}$, labile $\mathrm{N}$ and mineralization rate compared to sites mulched with shredded wood pallets. In the same study, microbial organisms immobilized up to $83 \%$ of the total pool of $\mathrm{N}$ in the

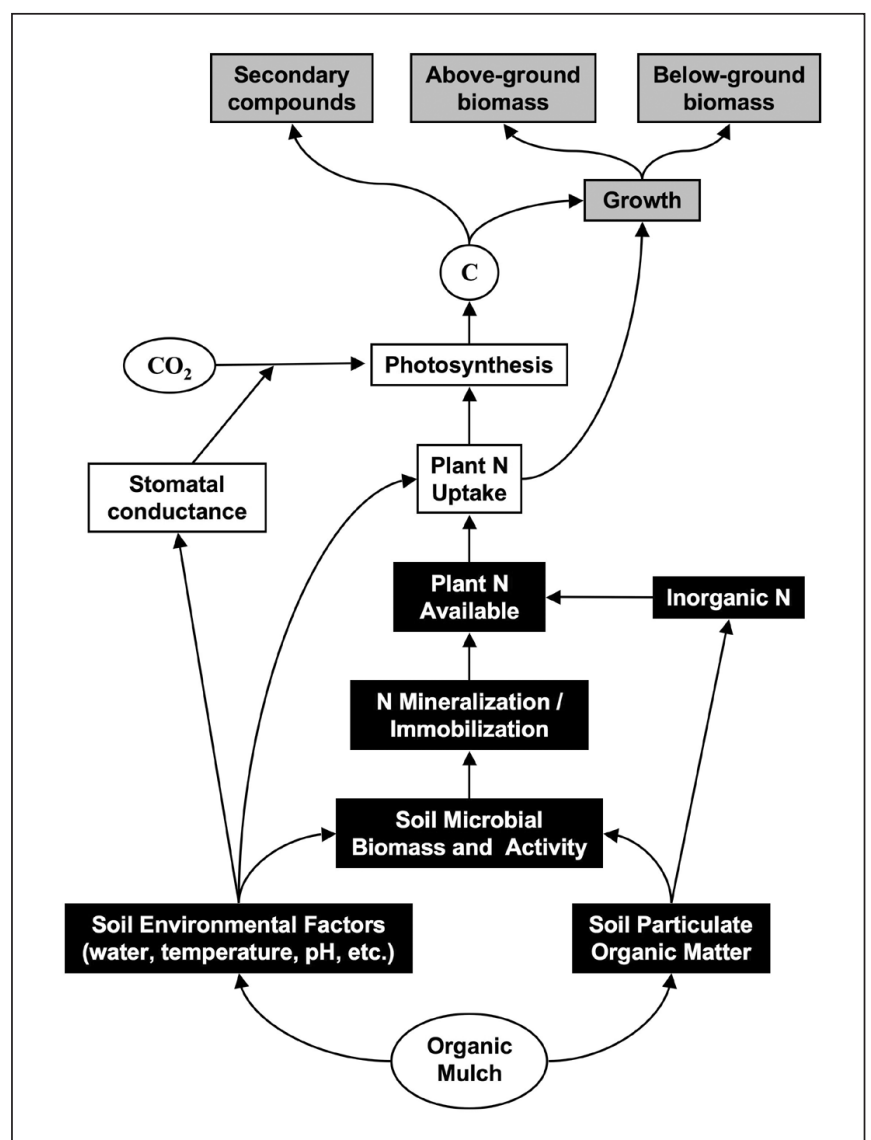

Figure 1. Conceptual model illustrating the effect of organic mulches on plant nitrogen $(\mathrm{N})$ and carbon $(\mathrm{C})$ uptake, and $\mathrm{C}$ allocation. White circles represent main inputs and transitional forms of $\mathrm{C}$ in the mode. Black squares represent processes associated with soil $\mathrm{N}$ availability and soil environmental conditions. White squares represent plant processes associated with resource acquisition. Gray squares represent plant processes associated with photosynthate allocation.

soils after mulching with shredded wood pallets. These results support the study of Sønsteby et al. (2004) where the amount of both ammonia and nitrate, were lower on mulched soil with bark chips (C:N 135:1) compared to nonmulched soils.

The association between organic matter $\mathrm{C}: \mathrm{N}$ ratio and the amount of $\mathrm{N}$ released during decomposition can be explained using a metabolic approach. Overall, soil microorganisms require one atom of $\mathrm{N}$ for the consumption of a substrate containing 20 atoms of $\mathrm{C}$ (Davet 2004). During decomposition of organic matter with $\mathrm{C}: \mathrm{N}$ ratio higher than 20 , microorganisms have to supplement their $\mathrm{N}$ demand by absorbing $\mathrm{N}$ from the soil solution (i.e., immobilization), which in many cases results in competition with surrounding plants. In contrast, when the organic matter C: $\mathrm{N}$ ratio is lower than 20 , excess $\mathrm{N}$ is excreted by the soil microorganisms in the form of inorganic $\mathrm{N}$ (i.e. mineralization) becoming available for the plants (Lambers et al. 1998; Davet 2004). This proportion of C to N can vary between 20 and 35 depending on the soil microbial community (Smith 1982).

Besides mulch chemical composition, soil conditions can also influence decomposition rates and consequently soil $\mathrm{N}$ availability. Microbial biomass and activity are sensitive to changes of soil 
$\mathrm{pH}$, temperature, moisture and aeration (Davet 2004). However, the responses to change in these variables fluctuate among decomposer community. For example, fungi are able to develop and reproduce in a $\mathrm{pH}$ range of 3.5 to 8.5 while most bacteria cannot survive at a pH lower than 6.5 (Davet 2004). In addition, extremes in temperature and soil moisture reduce decomposition rates of organic matter because they decrease metabolic activities of microorganisms (Swift and Anderson 1989; Barrett and Burke 2000).

Extant nutrients in the soil may also affect mulch decomposition by providing nutrients needed by microbes during decomposition (Torn et al. 2005). However, some contrasting results have been reported between studies comparing organic matter decomposition rates in fertilized and nonfertilized soil. Torn et al. (2005) and Hobbie (2005) reported positive and significant correlation between litter decomposition rate and soil nitrogen availability in nonfertilized soil. This correlation however, was not detected when soil at the same study site was $\mathrm{N}$-fertilized. Three potential explanation for these conflicting patterns are: (1) decomposition process was not $\mathrm{N}$ limited (Torn et al. 2005), (2) decomposition was more limited by poor C quality (e.g., high lignin content) than by $\mathrm{N}$ availability (Hobbie 2000), and (3) there was an inhibitory effect of supplied $\mathrm{N}$ on microbial synthesis of lignolytic enzymes (Hobbie and Vitousek 2000; Torn et al. 2005). More studies are needed to understand what is causing the inconsistent effects of soil $\mathrm{N}$ content on mulch decomposition between fertilized and nonfertilized soils.

In agro-forestry systems, mulching with blends of organic residue with contrasting $\mathrm{C}: \mathrm{N}$ ratios is recommended as an alternative to enhance soil $\mathrm{N}$ content without adding fertilizer. Some advantages of this practice include: reduction of leaching losses, prolongation of nutrient availability and synchronization of nutrient release with plant demands (Myers et al. 1994; Fortuna et al. 2003). Schwendener et al. (2005) studied the effect of mixing high-C:N cacao litter with low-C:N leguminous litter on decomposition and soil $\mathrm{N}$ dynamics in a cacao agro-forest system. In this study, legume leaves decomposed faster than cacao leaves without affecting the decomposition rate of cacao leaves during the time of the experiment (96 days). In addition, total soil $\mathrm{N}$ and microbial activity increased proportional to the amount of legume litter in the mulch mixture. These results suggest that $\mathrm{N}$ availability of mulched soils with high C:N substrates $(>20)$ can be improved by adding low $\mathrm{C}: \mathrm{N}(<20)$ organic material to the mulch.

\section{Resource Acquisition}

Changes of soil water and $\mathrm{N}$ availability by mulching can have a direct effect on the amount of $\mathrm{C}$ and $\mathrm{N}$ acquired by plants. Several studies have documented that acquisition of $\mathrm{N}$ by plants is directly related to the abundance of inorganic $\mathrm{N}$ in the soil (Min et al. 1999; Aerts and Chapin 2000). As mentioned before, most plants incorporate the majority of $\mathrm{N}$ in the inorganic forms $\left(\mathrm{NH}_{4}^{+}\right.$and $\left.\mathrm{NO}_{3}^{-}\right)$. Higher concentrations of $\mathrm{NH}_{4}^{+}$and $\mathrm{NO}_{3}^{-}$in the soil can trigger the synthesis of nitrate reductase and glutamine synthase in plants (Oaks 1994). These enzymes are indispensable for the assimilation of $\mathrm{NO}_{3}^{-}$and $\mathrm{NH}_{4}^{+}$, respectively.

A close relationship between $\mathrm{N}$ acquisition and $\mathrm{C}$ acquisition has been well documented (Field and Mooney 1986). In forest systems, net primary productivity (NPP) of individual trees and entire forest stands are positively correlated with soil $\mathrm{N}$ availability (Oren et al. 1985; Aerts 1989; Aerts and Decaluwe 1989;
Sampson et al. 2006). The enhancement in productivity occurs mostly because of the increase in total foliar mass. At stand level and when levels of available soil $\mathrm{N}$ increase, plants allocate more resources to leaf production (Millard and Proe 1991). In this way, trees can optimize the acquired $\mathrm{N}$ for $\mathrm{C}$ assimilation (Field 1983). Although NPP can also be enhanced by an increase in leaf photosynthetic ratio (Farquhar 1978; Shadchina and Beloivan 1993), studies with woody plants of different taxa have reported no significant effect of $\mathrm{N}$-fertilization on specific leaf photosynthetic ratio (Laitinen et al. 2000; Merilo et al. 2006).

Depending on the soil type, low soil water recharging rate promoted by thick layers of organic mulches can also limit $\mathrm{C}$ acquisition. Levels of $\mathrm{C}$ assimilation are determined by the amount of $\mathrm{CO}_{2}$ entering the leaves through the stomatal aperture. Two dominant factors controlling stomatal conductance among plant species are: (1) the availability of water in the soil and (2) the particular water use efficiency of each species (Marshall and Zhang 1994; Korol et al. 1999). Chapin (1991) proposed a physiological mechanism to explain how water stress can affect stomatal conductance. Under water stress conditions, the biosynthesis of abscisic acid in the roots is transferred to the leaves. This phytohormone is responsible for decreasing the stomatal aperture and reducing the water loss. Consequently, both transpiration and $\mathrm{C}$ uptake rates are constrained.

\section{Resource Allocation}

In terms of resource allocation, the model (Figure 1) has a particular focus on a plant's ability to allocate photosynthate between growth and production of secondary compounds. Evidence in the literature suggests that manipulation of nutrient dynamics in the soil can influence patterns of photosynthate allocation between growth and the production of secondary compounds (Herms and Mattson 1992; McKinnon and Quiring 1998; Glynn et al. 2003). For example, Wilkens et al. (1996) found that dry mass of tomato plant was positively correlated to the amount of fertilizer applied. However, the foliar concentration of two phenolics (rutin and chlorogenic acid) showed a parabolic relationship, with the highest concentrations of each at intermediate levels of fertilization. This pattern has been associated with plant defense hypotheses such as the Growth-Differentiation Balance (GDB) hypothesis because, in many cases, secondary compounds serve as natural defenses against pathogens and insect herbivores. Loomis (1953) and Herms and Mattson (1992) described the physiological mechanisms associated with the patterns of $\mathrm{C}$ allocation between growth and secondary compounds under different levels of resource availability. They contend that: (i) the assimilation of photosynthate to biomass and the synthesis of secondary metabolites are negatively correlated because both are dependent upon the same $\mathrm{C}$ pool of photosynthates. That (ii) under conditions of high resource availability, plant photosynthates are preferentially allocated to biomass accumulation. Finally, (iii) any condition slowing biomass accumulation more than $\mathrm{C}$ acquisition through photosynthesis (e.g., moderated levels of water or $\mathrm{N}$ availability) will increase the pool of photosynthates available for the synthesis of secondary compounds.

Alternatively, during the 1980s, a number of studies suggested that forest stands with "vigorous" trees (i.e., trees with high growing rates) are more resistant to herbivory (Larsson et al. 1983; Mitchell et al. 1983; Christiansen et al. 1987) and pathogen out- 
breaks (Matson and Waring 1984; Oren et al. 1985; Waring et al. 1987). This hypothesis was based on studies that examined mountain pine beetle outbreaks (Dendroctonus ponderosae). In these studies, stand wood production per unit of leaf area increased after thinning and fertilizing. Contrary to the GDB hypothesis, Waring and Pitman (1985) proposed that trees prioritize photosynthate allocation as follows: new foliage $>$ new roots $>$ storage $>$ diameter growth $>$ chemical defenses. Under this assumption, trees growing under dense canopy are more susceptible to herbivores because they receive lower levels of photosynthetic active radiation and overall produce less photosynthate. Therefore, the amount of photosynthate available for synthesis of chemical defenses become limited and trees become more susceptible to herbivores. Waring and Pitman (1985) and Waring et al. (1992) recommended stand fertilization and thinning as pest control management strategies.

Because of forest fertilization studies, fertilization has been adopted in urban landscapes as a managements practice to improve pest resistance properties on urban trees (see Herms 2002). This recommendation, clearly contradicts Lorio's (1986) point of view of a physiological trade-off between photosynthate allocation to growth or to synthesis of chemical defenses. Lorio (1986) used the GDB hypothesis to explain how the synthesis of oleoresin [principle defensive chemicals against bark beetles (Ruel et al. 1998)] can be reduced during periods of rapid growth, creating an opportunity for bark beetle attack. Lorio's proposition was supported by studies using a variety of botanical taxa (Bryant et al. 1987, Bryant et al.1988, Hunter and Shultz 1995, Villalba et al. 2002). These studies showed that nutrient enhancement delayed long-term induced chemical defenses and improved the palatability of foliage to herbivores.

\section{IMPLICATIONS FOR ARBORICULTURE}

The International Society of Arboriculture recommends applying 5 to $10 \mathrm{~cm}$ of organic mulches around trees to improve aesthetics and edaphic conditions in the landscape (ISA 2004). The reviewed literature in this paper supports this recommendation. This study also concludes that organic mulches can directly affect soil water and $\mathrm{N}$ availability with indirect consequences for plant photosynthate allocation. Plant physiological response is species specific and depends on mulch material, and on soil properties such as fertility, water holding capacity and $\mathrm{pH}$. However, the information compiled in this paper also illustrates general physiological and ecological consequences for plants after altering edaphic conditions through mulching. These general consequences are illustrated in the conceptual model (Figure 1).

It is also suggested that the controversy between Waring's and Lorio's points of view (i.e., photosynthate allocation priority versus photosynthates trade-off between growth and chemical defenses) is present in urban systems. Furthermore, that the experimental evidence supporting the use of fertilizer to enhance tree pest resistance is scarce and inconclusive. In fact, evidence suggests fertilization enhances insect performance by redirecting the resources allocated to defense and/or by increasing the palatability of the host plant (Herms 2002). These contradictory results reveal the necessity for additional studies that will help us understand the implication of mulching on tree physiological responses that affect their ecological, aesthetic, and economic value.
Acknowledgments. The authors thank Robert Tripepi, Yaniria Sanchez-de Leon and two anonymous reviewers for their suggestions. We also thank the TREE Fund (John Duling Grant), the University of Idaho's (UI) Stillinger Grant Program, and the UI's Department of Plant, Soil and Entomological Sciences for financial and logistic support.
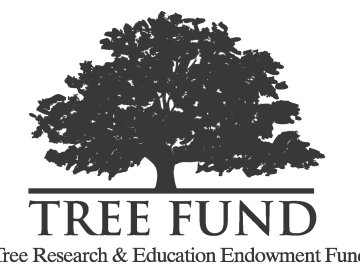

\section{LITERATURE CITED}

Acquaah, G. 2004. Horticulture: Principles and practices. Prentice Hall, Upper Saddle River, New Jersey. pp. 744-760.

Aerts, R., 1989. The effect of increased nutrient availability on leaf turnover and above-ground productivity of two evergreen ericaceous shrubs. Oecologia 78(1):115-120.

Aerts, R., and F.S. Chapin, III. 2000. The mineral nutrition of wild plants revised: a re-evaluation of processes and patterns. Advances in Ecological Research 30:1-67.

Aerts, R., and H. De Caluwe. 1997. Nutritional and plant-mediated controls on leaf litter decomposition of Carex species. Ecology 78(1):244-260

Aerts, R. and H. Decaluwe 1989. Above ground productivity and nutrient turnover of molinia-caerulea along an experimental gradient of nutrient availability. Oikos 54(3):320-324.

Appleton, B.L., J.F. Derr, and B.B. Ross. 1990. The effect of various landscape weed control measures on soil moisture and temperature and tree root growth. Journal of Arboriculture 16(10):264-268.

Barrett, J.E., and I.C. Burke. 2000. Potential nitrogen immobilization in grassland soils across a soil organic matter gradient. Soil Biology and Biochemistry 32(11-12):1707-1716.

Brady, N.C., and R.R. Weil. 1999. The nature and properties of soils, 12th. New Jersey, Upper Saddle River.

Bryant, J.P., T.P. Clausen, P.B. Reichardt, M.C. McCarthy, and R.A. Werner. 1987. Effect of nitrogen fertilization upon the secondary chemistry and nutritional value of quaking aspen (Populus tremuloides Michx.) leaves for the large aspen tortrix (Choristoneura conflictana (Walker)). Oecologia 73(4):513-517.

Bryant J.P., J. Tuomi, and P. Niemela. 1988. Environmental constrain of constitutive and long-term inducible defenses in woody plants. Chemical Mediation of Coevolution. K. Spencer. San Diego, California, USA, Academic Press: 376-389.

Buerkert, A., A. Bationo, and K. Dossa. 2000. Mechanisms of residue mulch induced cereal growth increases in West Africa. Soil Science Society of America Journal 64(1):346-358.

Bussiere, F., and P. Cellier. 1994. Modification of the soil temperature and water content regimes by a crop residue mulch: experiment and modeling. Agricultural and Forest Meteorology 68(1-2):1-28.

Chapin, F.S., III. 1991. Integrated responses of plants to stress. Bioscience 41(1):29-36.

Chapin, F.S., III. 1995. New cog in the nitrogen cycle. Nature 377(6546):199-200.

Christiansen E., R.H., Waring, and A.A. Berryman. 1987. Resistance of conifers to bark beetle attack: searching for general relationships. Forest Ecology and Management 22(1-2):89-106.

Cook, H.F., Valdes G.S.B., and Lee H.C. 2006. Mulch effects on rainfall interception, soil physical characteristics and temperature under Zea mays L. Soil \& Tillage Research 91(1-2):227-235. 
Davet, P. 2004. Microbial Ecology of the Soil and Plant Growth. Enfire, New Hampshire, Science Publishers: 125-126.

De Vleeschauwer, D., R. Lal, and R. Malafa. 1980. Effects of amounts of surface mulch on physical and chemical properties of an alfisol from $\mathrm{Ni}$ geria. Journal of the Science of Food and Agriculture 31(7):730-738.

Erhart, E., and W. Hartl. 2003. Mulching with compost improves growth of blue spruce in Christmas tree plantations. European Journal of Soil Biology 39(3):149-156.

Farquhar, G. D. 1978. Carbon assimilation in relation to transpiration and fluxes of ammonia. Photosynthesis and Plant Development, Limburgs Universitair Centrum, Diepenbeek, Belguim, Dr W. Junk bv Publishers.

Field, C. 1983. Allocating leaf nitrogen for the maximization of carbon gain: Leaf age as a control on the allocation program. Oecologia 56(2-3):341-347.

Field, C.B., and H.A. Mooney. 1986. The photosynthesis-nitrogen relationship in wild plants. On The Economy of Plants Form and Function. T. J. Givnish (Ed.). Cambridge, Cambridge University Press: $25-55$.

Fortuna, A., R.R. Harwood, G.P. Robertson, J.W. Fisk, and E.A. Paul. 2003. Seasonal changes in nitrification potential associated with application of $\mathrm{N}$ fertilizer and compost in maize systems of southwest Michigan. Agriculture, Ecosystems and Environment 97:285-293.

Glynn, C., D.A. Herms, M. Egawa, R. Hansen, and W.J. Mattson. 2003. Effects of nutrient availability on biomass allocation as well as constitutive and rapid induced herbivore resistance in poplar. Oikos 101(2):385-397.

Gilman, E.F. and J. Grabosky. 2004. Mulch and planting depth affect live oak (Quercus virginiana Mill.) establishment. Journal of Arboriculture 30(5):311-317.

Herms, D., M. Gleason, J. Iles, D. Lewis, H. Hoitink, and J. Hartman. 2001. Using mulches in managed landscapes. Sustainable Urban Landscapes, Iowa State University, Continuing Education and Communication Services. Bulletin 894.

Herms, D.A., 2002. Effects of fertilization on insect resistance of woody ornamental plants: Reassessing an entrenched paradigm. Environmental Entomology 31(6):923-933.

Herms, D.A., and W.J. Mattson. 1992. The dilemma of plants to grow or defend. Quarterly Review of Biology 67(3):283-335.

Hobbie, S.E., and P.M. Vitousek. 2000. Nutrient limitation of decomposition in Hawaiian forests. Ecology 81(7):1867-1877.

Hobbie, S.E., 2000. Interactions between litter lignin and soil nitrogen availability during leaf litter decomposition in a Hawaiian montane forest. Ecosystems 3:484-494.

Hobbie, S.E., 2005. Contrasting effects of substrate and fertilizer nitrogen on the early stages of litter decomposition. Ecosystems 8:644-656.

Hunter, M.D., and J.C. Schultz. 1995. Fertilization mitigates chemical induction and herbivore responses within damaged oak trees. Ecology 76(4):1226-1232.

International Society of Arboriculture (ISA). 2004. Proper mulching techniques. Retrieved October 29, 2008, from: http://www.treesaregood.org/treecare/mulching.aspx.

Iles, J.K., and M.S. Dosmann. 1999. Effect of organic and mineral mulches on soil properties and growth of Fairview Flame red maple trees. Journal of Arboriculture 25(3):163-167.

Korol, R.L., M.U.F. Kirschbaum, G.D. Farquhar, and M. Jeffreys. 1999. Effects of water status and soil fertility on the C-isotope signature in Pinus radiata. Tree Physiology 19(9):551-562.

Laitinen, K., E.M. Luomala, S. Kellomaki, E. Vapaavuori. 2000. Carbon assimilation and nitrogen in needles of fertilized and unfertilized field-grown Scots pine at natural and elevated concentrations of $\mathrm{CO} 2$. Tree Physiology 20(13):881-892.

Lambers, H., F.S. Chapin, and T.L. Pons. 1998. Plant Physiological Ecology. New York, Springer.

Larsson, S., R. Oren, R.H. Waring, and J.W. Barrett. 1983. Attacks of mountain pine beetle as related to tree vigor of ponderosa pine. Forest Science 29(2):395-402.

Lloyd, J.E., D.A. Herms, B.R. Stinner and H.A.J. Hoitink. 2002. Comparing composted yard trimmings and ground wood as mulches. Biocycle 43(9):52+.

Loomis, W. E. 1953. Growth and differentiation: An introduction and summary. Growth and Differentiation in Plants. W. E. Loomis. Ames, Iowa, Iowa State College Press: 1-17.

Lorio, P.L. 1986. Growth-differentiation balance: a basis for understanding southern pine-beetle tree interactions. Forest Ecology and Management 14(4):259-273.

Marshall, J.D., and J. W. Zhang. 1994. Carbon isotope discrimination and water use efficiency in native plants of the north central Rockies. Ecology 75(7):1887-1895.

Matson, P.A., and R.H. Waring. 1984. Effects of nutrient and light limitation on mountain hemlock: Susceptibility to laminated root-rot. Ecology 65(5):1517-1524.

Mbagwu, J.S.C. 1991. Influence of different mulch materials on soil temperature, soil water content and yield of three cassava cultivars. Journal of the Science of Food and Agriculture 54(4):569-577.

McKinnon, M.L., and D.T. Quiring. 1998. Influence of resource availability on growth and foliar chemistry within and among young white spruce trees. Ecoscience 5(3):295-305.

Merilo, E., K. Heinsoo, O. Kull, I. Söderbergh, T. Lundmark, and A. Koppel. 2006. Leaf photosynthetic properties in a willow (Salix viminalis and Salix dasyclados) plantation in response to fertilization. European Journal of Forest Research 125:93-100.

Melillo, J.M., J.D. Aber and J.F. Muratore. 1982. Nitrogen and lignin control of hardwood leaf litter decomposition dynamics. Ecology 63(3):621-626.

Millard, P., and M. F. Proe. 1991. Leaf demography and the seasonal internal cycling of nitrogen in sycamore (Acer pseudoplatanus L.) seedlings in relation to nitrogen supply. New Phytologist 117(4):587-596.

Min, X., M.Y. Siddiqi, R.D. Guy, A.D.M. Glass, and H.J. Kronzucker. 1999. A comparative study of fluxes and compartmentation of nitrate and ammonium in early-successional tree species. Plant Cell and Environment 22(7):821-830.

Mitchell, R.G., R.H. Waring, and G.B. Pitman. 1983. Thinning lodgepole pine increases tree vigor and resistance to mountain pine beetle. Forest Science 29(1):204-211.

Myers, R.J.K., C.A. Palm, E. Cuevas, I.U.N. Gunatilleke, and M. Brossard. 1994. The synchronization of nutrient mineralization and plant nutrient demand. Biological Management of Tropical Soil Fertility. P. L. Woomer and M. J. Swift. Chichester, UK, Wiley:81-116.

Northup, R.R., Z. Yu, R.A. Dahlgren, and K.A. Vogt. 1995. Polyphenol control of nitrogen release from pine litter. Nature 377(6546):227-229.

Oaks, A. 1994. Primary nitrogen assimilation in higher plants and its regulation. Canadian Journal of Botany 72(6):739-750.

Oren, R., W.G. Thies, and R.H. Waring. 1985. Tree vigor and stand growth of Douglas fir as influenced by laminated root-rot. Canadian Journal of Forest Research 15(5):985-988.

Proe, M.F., A.D. Cameron, J. Dutch, and X.C. Christodoulou. 1996. The effect of whole-tree harvesting on the growth of second rotation Stika spruce. Forestry 69(4):389-401. 
Ruel, J.J., M.P. Ayres, and P.L. Lorio, Jr. 1998. Loblolly pine responds to mechanical wounding with increasing resin flow. Canadian Journal of Forest Research 28:596-602.

Sampson, D.A., R.H. Waring, C.A. Maier, C.M. Gough, M.J. Ducey, and K.H. Johnsen. 2006. Fertilization effects on forest carbon storage and exchange, and net primary production: A new hybrid process model for stand management. Forest Ecology and Management 221(1-3):91-109.

Schwendener, C.M., J. Lehmann, P.B.D. Camargo, R.C.C. Luizão, and E.C.M. Fernandes. 2005. Nitrogen transfer between high- and lowquality leaves on a nutrient-poor oxisol determined by ${ }^{15} \mathrm{~N}$ enrichment. Soil Biology \& Biochemistry 37:787-794.

Seneviratne, G. 2000. Litter quality and nitrogen release in tropical agriculture: a synthesis. Biology and Fertility of Soils 31(1):60-64.

Shadchina, T.M., and O. A. Beloivan. 1993. Effect of different nitrogen supply on chloroplast pigment-protein complexes in maize. Photosynthetica 28(3):415-422.

Smith, O.L. 1982. Soil microbiology: a model of decomposition and nutrient cycling. Matemetical Models in Microbiology. M.J. Bazin. Boca Raton, Fla., CRC Press: 209-210.

Sønsteby, A., A. Nes, and F. Måge. 2004. Effects of bark mulch and NPK fertilizer on yield, leaf nutrient status and soil mineral nitrogen during three years of strawberry production. Acta agriculturae Scandinavica 54(3):128-134.

Swift, M.J., and J.M. Anderson. 1989. Decomposition. Ecosystems of the World, 14B. Tropical Rain Forest Ecosystems, Biogeography and Ecological Studies. H. Lieth and M.J.A. Werger. Amsterdam, Elsevier. 2:547-569.

Torn, M.S., P.M. Vitousek, and S.E. Trumbore. 2005. The influence of nutrient availability on soil organic matter turnover estimated by incubations and radiocarbon modeling. Ecosystems 8(4):352-372.

Villalba, J.J., F.D. Provenza, and J.P. Bryant. 2002. Consequences of the interaction between nutrients and plant secondary metabolites on herbivore selectivity: benefits or detriments for plants? Oikos 97(2):282-292.

Vitousek, P.M., J.R. Gosz, C.C. Grier, J.M. Melillo, and W.A. Reiners. 1982. A comparative analysis of potential nitrification and nitrate mobility in forest ecosystems. Ecological Monographs 52(2):155-177.
Vitousek, P.M., D.R. Turner, W.J. Parton, and R.L. Sanford. 1994. Litter Decomposition on the Mauna Loa Environmental Matrix, Hawai'i: Patterns, Mechanisms, and Models. Ecology 75(2):418-429.

Waring, R.H., K. Cromack, P.A. Matson, R.D. Boone, and S.G. Stafford. 1987. Responses to pathogen-induced disturbance: Decomposition, nutrient availability, and tree vigor. Forestry 60(2):219-227.

Waring, R.H., and G.B. Pitman. 1985. Modifying lodgepole pine stands to change susceptibility to mountain pine beetle attack. Ecology 66(3):889-897.

Waring, R.H, T. Savage, K. Cromack, Jr., and C. Rose. 1992. Thinning and nitrogen fertilization in a grand fir stand infested with western spruce budworm. IV. An ecosystem management perspective. Forest Science 38(2):275-286.

Watson, G.W., and G. Kupkowski. 1991. Effect of deep layer of mulch on the soil environment and tree root growth. Journal of Arboriculture 17(9):242-245.

Wilkens, R.T., J.M. Spoerke, and N.E. Stamp. 1996. Differential responses of growth and two soluble phenolics of tomato to resource availability. Ecology 77(1):247-258.

Javier Lugo-Perez, (corresponding author)

Research Specialist

Department of Biological Sciences

University of Illinois at Chicago

845 West Taylor Street

Chicago, IL 60607, U.S.

javierlp@uic.edu

John E. Lloyd

Director of Research and Science

Rainbow Treecare West Metro

$11571 \mathrm{~K}$-Tel Dr

Minnetonka, MN 55343, U.S.

JLloyd@RainbowTreecare.com 
Résumé. En plus des bénéfices esthétiques et pratiques des paillis, des études ont démontré des bénéfices indirects provenant des paillis organiques, et ce sur la reprise des arbres et leur croissance. Ces bénéfices indirects sont associés à des améliorations directes sur la disponibilité en eau et en éléments minéraux par les paillis. La généralisation des bénéfices au sol et aux arbres par les paillis organiques a été questionnée par plusieurs études qui montraient des résultats contradictoires sous différentes conditions expérimentales et différents paillis. De plus, l'ensemble des bénéfices pour les arbres peuvent avoir été occultés par des études ciblées sur certaines aspects de la performance de la plante (ex.: taux de croissance de la plante) qui en occultaient d'autres (ex.: défense chimique de la plante). Dans cet article, nous faisons une revue des études qui démontrent comment les paillis organiques peuvent directement affecter la disponibilité en ressources du sol pour la plante. Nous présentons des faits provenant de la littérature qui illustrent que l'influence des paillis organiques sur la disponibilité en ressources pour la plante peut aussi affecter les dynamiques d'allocation des photosynthate de l'arbre, et ce avec des conséquences directes sur les défenses chimiques de la plante. En se basant sur cette revue de littérature, nous présentons un cheminement mécanistique pour illustrer comment les paillis organiques peuvent influencer les ressources pour la plante dans le sol, et en retour comment cela peut affecter la physiologie de l'arbre et l'interaction arbre-insectes en milieux urbains.

Zussamenfassung. Zusätzlich zu den ästethischen und praktischen Vorteilen von Mulchen, haben Studien auch indirekte Vorteile von organischen Mulchen für die Baumetablierung und Wachstum gezeigt. Diese indirekten Vorteile stehen mit den direkten Einflüssen auf Bodenwasser und Nährstoffverfügbarkeit von Mulchmaterialien in Verbindung. Die Verallgemeinerung von organischen Mulchen und ihrem Beitrag zu Boden und Bäumen wurde in verschiedenen Studien hinterfragt und man ist dort auch zu widersprüchlichen Ergebnissen gekommen unter verschiedenen Bedingungen und Mulchmaterialien. Zusätzlich können die allgemeinen Vorteile des Mulchens für Bäume leicht übersehen werden, wenn auf Studien fokussiert wird, die Telaspekte von Leistung (z.B.
Wachstumsrate) hervorheben und andere (z.B. chemische Verteidigung der Pflanzen) außer Acht lassen. In dieser Studie geben wir einen Überblick über Studien, wie organische Mulche direkt die Verfügbarkeit der Ressourcen im Boden beeinflusst. Wir präsentieren Nachweise aus der Literatur, die verdeutlicht, dass der Einfluss von organischen Mulchen auf Pflanzenverfügbarkeit von Nährstoffen auch die Photosynthese beeinflussen kann, mit direkten Konsequenzen für die chemische Verteidigung der Pflanze. Basierend auf diesem Literaturüberblick präsentieren wir hier einen mechanischen Weg zur Illustration, wie stark organische Mulche die Pflanzenverfügbarkeit von Nährstoffen im Boden beeinflussen und wie das wiederum die Baumphysiologie und Baum-InsektenInteraktionen in städtischen Gebieten verändern kann.

Resumen. Además de los beneficios estéticos y prácticos del mulching, los estudios han mostrado los beneficios indirectos de los mulches orgánicos para el establecimiento y crecimiento de los árboles. Estos beneficios indirectos están asociados con el mejoramiento de la disponibilidad de agua y elementos del suelo por los mulches. La generalización de los beneficios de los mulches orgánicos al suelo y los árboles ha sido cuestionada por varios estudios que muestran resultados contradictorios bajo diferentes condiciones experimentales y materiales de mulching. Además, los beneficios para los árboles pueden ser pasados por alto al enfocarse en algunos aspectos del comportamiento de la planta (por ej. tasa de crecimiento de la planta) e ignorando otros (por ej. defensa química de la planta) En este reporte, se revisan estudios mostrando cómo los mulches orgánicos pueden afectar directamente la disponibilidad de recursos en el suelo. Se presentan evidencias de la literatura mostrando que la influencia de los mulches orgánicos en la disponibilidad de recursos para la planta puede también afectar las dinámicas fotosintéticas con consecuencias directas en las defensas químicas de la planta. Con la revisión de literatura, se presentan un sendero mecanicista que ilustra cómo los mulches orgánicos pueden influir en los recursos para la planta en el suelo, y cómo pueden afectar la fisiología del árbol y las interacciones árbol-insecto en áreas urbanas. 